\title{
PERAN INOVASI PRODUK MEMEDIASI ORIENTASI TEKNOLOGI TERHADAP KEUNGGULAN BERSAING
}

\author{
Putu Gde Kamasaka Widiarta ${ }^{1}$ \\ I Putu Dicky Mahardika ${ }^{2}$ \\ Nyoman Agus Surya Nugraha ${ }^{3}$ \\ I Dewa Gede Wilanta Tintara ${ }^{4}$ \\ Ni Nyoman Kerti Yasa ${ }^{5}$
}

Fakultas Ekonomi dan Bisnis, Universitas Udayana, Bali, Indonesia ${ }^{1,2,3,4,5}$
E-mail: kamasakawidiarta@gmail.com / telp: 081238376499

\begin{abstract}
This study discusses to explain the Role of Product Innovation Mediating Technology Orientation to Competitive Advantages. The sample used was 62respondents obtained using non probability sampling method consisting of purposive sampling residing in the city of Denpasar, and having made transactions or used the services of Gojek. Data was collected using a full questionnaire and using a Likert scale. Data were analyzed using path analysis techniques and sobel tests. The results of this study prove that technological orientation is positive and significant towards the product innovation and competitive advantage. Product innovation are positive and significant to competitive advantage. Supported product innovation mediates an integrated orientation to competitive advantage. The implications of this research provide advice for Gojek Indonesia to support product improvement and pay attention to technological orientation related to the creation of superior competitiveness.
\end{abstract}

Keywords: Product innovation; Competitive advantages; Technology orientation.

\begin{abstract}
ABSTRAK
Studi ini bertujuan untuk menjelaskan Peran Inovasi Produk Memediasi Orientasi Teknologi terhadap Keunggulan Bersaing. Sampel yang digunakan sebanyak 62 responden yang diperoleh dengan menggunakan metode non probability sampling berbentuk purposive sampling yang bertempat tinggal di Kota Denpasar, dan pernah melakukan transaksi atau pemanfaatan layanan dari Gojek.Data dikumpulkan dengan menyebarkan kuesioner secara langsung dan menggunakan skala Likert. Data dianalisis menggunakan teknik analisis jalur dan uji sobel.Hasil penelitian ini menunjukkan bahwaorientasi teknologi berpengaruh positif dan signifikan terhadap inovasi produk dan keunggulan bersaing. Inovasi produk berpengaruh positif dan signifikan terhadap keunggulan bersaing. Inovasi produk berperan secara signifikan memediasi pengaruh orientasi teknologi terhadap keunggulan bersaing. Implikasi penelitan ini memberikan saran kepada pihak Gojek Indonesia untuk secara berkelanjutan meningkatkan inovasi produk dan memerhatikan orientasi teknologi terkait dengan terciptanya daya saing yang unggul.
\end{abstract}

Kata kunci : Inovasi Produk; Keunggulan Bersaing; Orientasi Teknologi. 


\section{PENDAHULUAN}

Perkembangan bisnis di era globalisasi telah berjalan dengan pesat dan mengalami metamorfosis yang berkesinambungan. Para wirausahawan berlomba dan gencar pada kiatnya dalam melakukan peningkatan dari proses bisnis termasuk dalam mendistribusikanya kepada publik yang dalam hal ini adalah konsumen.Sejalan dengan itu, beragam jenis perusahaan muncul dengan sumber daya serta nilai kreasinya masing-masing yang salah satunya yaitu perusahaan rintisan digital yang sering disebut dengan Startup. Makna dari Startup merujuk pada pemahaman rintisan pada perusahaan berbasis digital yang belum lama beroperasi atau baru di mulai serta masih berada pada tahapan pengembangan dan penelitian untuk menemukan pangsa pasar yang tepat.

Istilah Startup pertama kali berawal dari area yang bernama Sillicon Valley(modalku.co.id) dan mulai populer secara internasional pada akhir tahun 1990-an yang pada periode tersebut dikenal dengan fenomena dot-com bubble. Ketika masa itu banyak perusahaan yang mayoritas beroperasi di wilayah Amerika Serikat, termasuk Sillicon Valley secara bersama-sama memberdayakan internet untuk membuat website pribadi perusahaan dengan basis dot-com. Hingga saat ini penyebaran Startup secara global masih berkembang dengan sangat pesat dan menjadi sorotan bagi investor di seluruh dunia.

Di Indonesia, jumlah perusahaan Startup telah berkembang dengan sangat masif. Terlepas dari fenomena krisis ekonomi pada tahun 2008 yang mengakibatkan melemahnya sendi-sendi sektor keuangan serta sektor riil, tidak melemahkan kreativitas dan daya juang para entrepreneur dalam membangkitkan 
kekuatan ekonomi yang telah terguncang oleh krisis. Para entrepreneur intens melakukan inovasi salah satu diantara yang telah terealisasikan adalah dengan mulai lahirnya perusahaan startup di Indonesia.

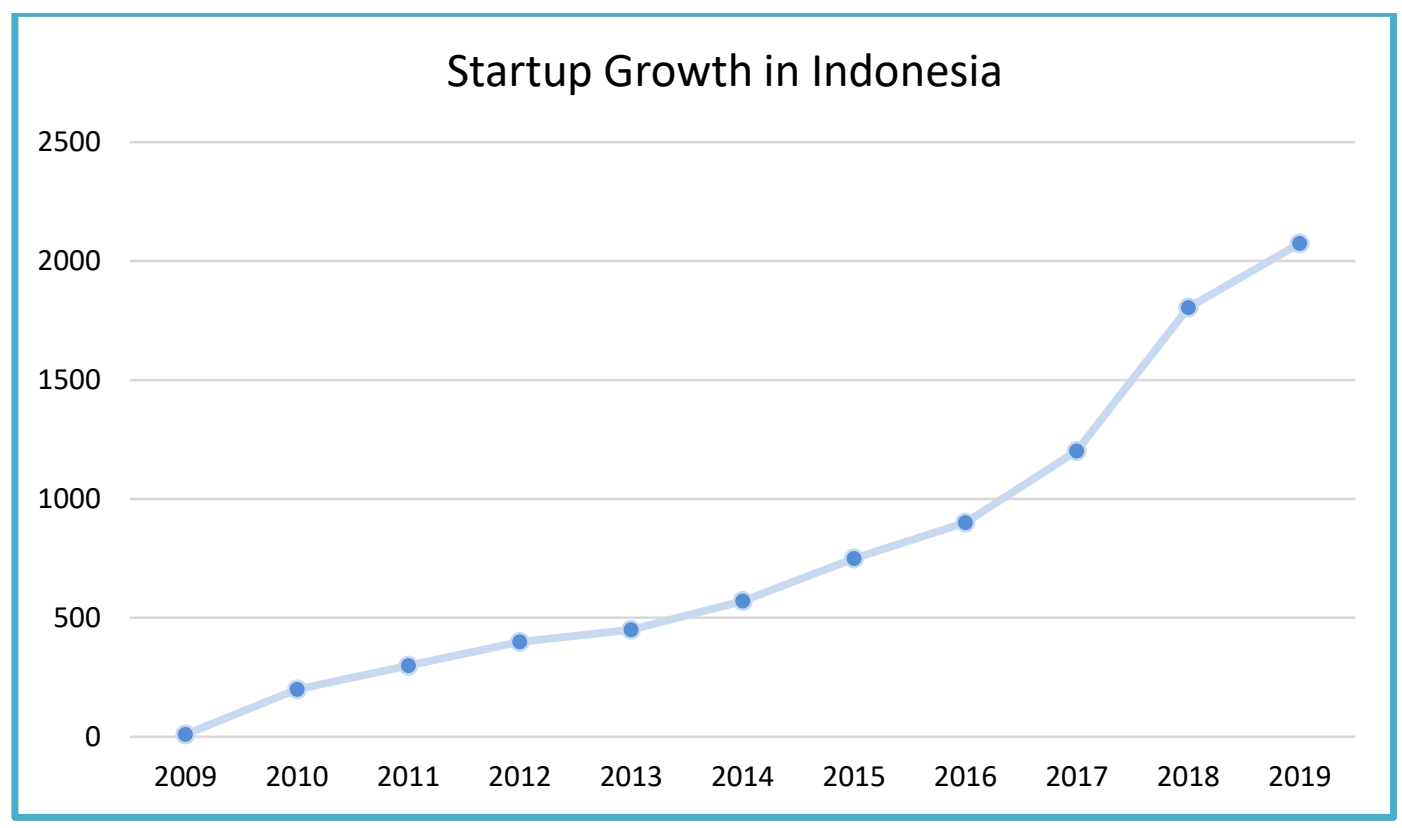

Sumber: Data Diolah, 2019

\section{Grafik 1.}

Pertumbuhan Perusahaan Startup di Indonesia

Berdasarkan data dari situs Startup Ranking(katadata.co.id), per 21 Maret 2019, telah tercatat sejumlah 2.074 startup dengan pertumbuhan tertinggi di tiga sektor yaitu on-demand services, financial technology (fintech) dan e-commerce. Dari sekian banyak startup yang sudah berdiri di Indonesia, beberapa telah mampu berevolusi menjadi startup dengan status unicorn atau dalam arti perusahaan yang memiliki valuasi setara atau melebihi USD 1 Miliar (Rp. 14,2 Triliun). Gojek hadir sebagai startup pertama Indonesia yang berhasil menyandang status unicorn. Bahkan per 5 Maret 2019, bersumber dari lembaga riset internasional bernama $C B$ Insights(katadata.co.id), Gojek telah mampu meningkatkan status perusahaan 
menjadi decacorn yang berarti perusahaan dengan nilai valuasi setara atau melebih USD 10 Miliar.

PT. Aplikasi Karya Anak Bangsa, yang terefleksikan melalui Gojek (gojek.com)telah berdiri sejak tahun 2010 oleh seorang pengusaha muda asal Indonesia bernama Nadiem Makarim yang menjabat sebagai CEO Gojek Indonesia dengan 3 nilai pilar utama yaitu kecepatan, inovasi, dan dampak sosial. Sebagai seorang entrepreneur, Nadiem Makarim bersama dengan rekan-rekannya ingin menjadikan Gojek sebagai perusahaan yang di samping memiliki tujuan pada aspek profitabilitas, Gojek bertekad mewujudkan misi sosial untuk meningkatkan kesejahteraan dan mata pencaharian pekerja di berbagai sektor informal melalui platform aplikasi mereka dengan mendapatkan akses santunan kesehatan/kecelakaan, jasa keuangan dan asuransi, serta pembayaran otomatis yang terjangkau dan banyak manfaat lainnya.

Gojek yang awalnya hanya beroperasi pada kegiatan transportasi, saat ini telah dapat meningkatkan basis mereka yang bermula dari hanya layanan ondemand transport beranjak dengan membangun kegiatan penyediaan lifestyle services yang sangat pokok untuk kehidupan sehari-hari di masyarakat. Ada 3 katagori layanan utama beserta pengembangannya yang disediakan pada platform aplikasi Gojek yaitu GO-JEK yang mencakup seluruh kegiatan transportasi dan kurir, GO-PAY yang terdiri dari layanan finansial, point, serta pulsa, dan GO-LIFE yang berisi layanan terkait gaya hidup. Dalam arti lain, Gojek telah menembus batas kreasinya sebagai perusahaan startup yang tidak hanya memerhatikan produk dan 
konsumen, melainkan serta dengan turut memerikan perhatian khusus terhadap para mitra kerjanya demi terwujudnya dampak sosial yang bermakna.

Namun seiring berjalannya waktu, dengan semakin banyaknya perusahaan startup beroperasi di berbagai sektor lini di Indonesia terlebih dengan startup yang memiliki kesamaan sektor dengan Gojek seperti Grab yang telah lebih dahulu menjadi startup dengan status decacorn pertama di Asia Tenggara(kompas.com). Tentu, fenomena tersebut akan memunculkan keadaan saling dominansi dan otomatis akan menciptakan persaingan yang sangat intens antar startup dalam memperebutkan pangsa pasar ideal di Indonesia khususnya wilayah Bali. Dampaknya, seluruh perusahaan rintisan digital melakukan kreasi nilai atas produk yang dipersiapkan untuk menciptakan peluang bisnis serta memenangkan target pasar. Agar itu dapat terealisasikan oleh Gojek, salah satu langkah yang dapat di ambil oleh perusahaan adalah dengan meningkatkan daya saing (Devie, 2013).

Pentingnya pemberdayaan sumber daya tidak lain demi untuk evolusi bisnis perusahaan kearah yang lebih maju dan menciptakan daya saing yang unggul dibanding kompetitor. Begitu juga dengan kondisi sekarang yang di hadapi oleh Gojek yang sangat serius dalam membangun daya saing perusahaan. Daya saing atau sering disebut dengan Keunggulan bersaing merupakan kemampuan perusahaan dalam memeroleh keuntungan ekonomis di atas laba yang mampu diraih oleh pesaing di pasar dalam industri yang sama. Perusahaan yang memiliki keunggulan bersaing cenderung memiliki kemampuan dalam memahami perubahan struktur pasar dan mampu memilih strategi pemasaran yang efektif (Porter, 2008). Penelitian oleh Noe et al. (2003), menyebutkan bahwa keunggulan 
bersaing adalah kemampuan perusahaan untuk membuat produk atau penawaran layanan yang lebih dihargai oleh pelanggan dibandingkan dengan perusahaan pesaing. Kotler dan Armstrong (2008) mendefisinikan keunggulan bersaing sebagai suatu keunggulan melebihi pesaing yang diraih dengan menawarkan nilai yang lebih besar kepada konsumen, baik melalui harga yang lebih rendah atau dengan menyediakan lebih banyak manfaat yang sesuai dengan harga yang lebih mahal. Keunggulan bersaing diperoleh melalui kumpulan faktor yang nantinya membedakan suatu perusahaan dari pesaingnya dan memberikan perusahaan tersebut posisi tersendiri di dalam pasar (Zimmerer dan Norman, 2002). Contoh dari perusahaan yang memiliki daya saing unggul adalah melaksanakan kreasi, kerjasama, opsi bersama yang berarti perusahaan melibatkan pihak ketiga yang kredibel seperti lembaga pemerintah independen, serta kompetisi dalam mendorong terobosan aktif baik dari segi struktur organisasi, proses, budaya perusahaan, teknologi serta sumber daya manusianya (Ma, 2004).

Salah satu faktor yang memengaruhi Keunggulan bersaing adalah Orientasi teknologi. Dalam penelitian Gatignon dan Xuereb (1997) menyatakan orientasi teknologi adalah kemampuan dan kemauan perusahaan untuk mengembangkan pola pikir teknologi dan memanfaatkannya dalam meningkatkan serta mengembangkan produk dan layanan. Pada perusahaan yang berorientasikan pada teknologi dapat diartikan bahwa perusahaan dapat menggunakan pengetahuan teknisnya guna menghasilkan solusi optimal dalam menjawab dan memenuhi kebutuhan dari penggunanya. Orientasi teknologi juga dipandang sebagai suatu orientasi strategis yang berbasiskan budaya, spesifik atas perusahaan dan terdiri dari 
kemampuan kompleks yang sesuai dengan basis pandangan sumber daya perusahaan (Day, 1994; Zhouet al.,2005). Perusahaan yang berorientasi teknologi diperlukan agar sejalan dengan misi dan visi perusahaan. Oleh karena itu, sesuai dengan arahan strategis, manajemen puncak harus memutuskan apakah akan mengembangkan teknologi secara internal atau diperoleh dari luar, sejauh mana berinvestasi pada Research \& Development (R\&D), memilih untuk bersaing atau bekerja sama dengan saingan, serta cara alternatif mana yang terbaik untuk perusahaan saat ini dan di masa depan (Morone, 1989). Selain itu, memastikan operasi perusahaan dijalankan dengan teknologi terkini, memutuskan jumlah dan arah investasi $\mathrm{R} \& \mathrm{D}$, serta memertimbangkan kemungkinan proyeksi di masa depan sebagai tanggung jawab manajemen perusahaan (Antoniou dan Ansoff, 2004).

Tampak bahwa orientasi teknologi mampu memerikan dampak positif bagi keunggulan bersaing pada suatu perusahaan. Nakola et al.(2015) menyatakan bahwa semakin positif perusahaan dalam mengimplementasikan orientasi teknologi, maka terciptanya daya saing yang unggul akan cenderung meningkat. Perusahan perlu mengalokasikan sumber daya untuk investasi dalam teknologi terbaru dan memrediksi perubahan teknologi di masa depan diikuti dengan peningkatan proses internal seperti kecepatan, keandalan, dan manajemen informasi secara komprehensif dalam mencapai keunggulan bersaing. Apabila perusahaan dapat mewujudkan serta membangun orientasi teknologi, akan memerikan dampak terciptanya suatu inovasi.Perusahaan yang berorientasi teknologi unggul dalam kemahiran teknis dan fleksibilitas, sebab mereka adalah 
pendorong penting untuk ide-ide inovatif dari inovasi proyek/produk perusahaan. (Liu dan Su, 2014)

Inovasi produk diartikan sebagai suatu pengenalan dan pengembangan jenis barang atau jasa baru yang berbeda dengan lebih menekankan pada segi kualitas (Atalay et al., 2013). Menurut Tung (2012) Inovasi produk merupakan pengenalan produk baru di pasar dengan menggunakan teknologi yang berbeda dan memiliki manfaat yang tinggi kepada konsumen. Inovasi adalah salah satu aspek penentu terhadap perusahaan, dalam lingkungan persaingan yang semakin ketat (Lin dan Chen, 2007). Perusahaan dapat melakukan terobosan dalam membuat, mengembangkan produk baru, ataupun memperbarui proses produksi dan distribusi sebuah produk dalam rangka bersaing secara kompetitif dengan pesaing dan juga mendapatkan segmen pasar baru (Mulyani, 2015).

Pengembangan produk baru dan strateginya yang efektif seringkali menjadi penentu keberhasilan dan kelangsungan hidup suatu perusahaan, akan tetapi itu bukanlah suatu hal yang mudah. Pengembangan produk baru memerlukan upaya, waktu, dan kemampuan termasuk besarnya resiko dan biaya kegagalan. Disisi lain perubahan lingkungan yang cepat akan mempengaruhi proses tersebut, hal ini menentukan efisiensi dalam inovasi produk (Hurley dan Hult, 1998). Jika perusahaan tidak serius di dalam membangun inovasi maka persaingan di pasar terkait dengan selera konsumen akan cenderung dapat teralih kepada kompetitor yang lebih memerhatikan aspek inovasi dan tentu akan berpengaruh pada keberlangsungan perusahaan di masa depan. 
Suendro (2010) menyatakan bahwa inovasi produk diperlukan untuk memenuhi permintaan pasar, diikuti dengan terwujudnya daya saing perusahaan. Inovasi produk yang dikembangkan akan dapat meningkatkan kemampuan dari perusahaan untuk menghasilkan produk yang berkualitas. Perusahaan sebaiknya mampu meningkatkan kemampuan pengembangan produk yang telah dilakukan dengan tujuan produk yang dihasilkan memiliki potensi yang dapat dikembangkan untuk inovasi berkelanjutan, serta dengan terciptanya inovasi khususnya pada segi produk maka akan mendorong perusahaan dalam mewujudkan suatu nilai atas daya saing yang unggul.

Berdasarkan pemaparan latar belakang masalah yang ada, maka tujuan penelitian ini, yaitu untuk menjelaskan peran inovasi produk dalam memediasi orientasi teknologi terhadap keunggulan bersaing. Kontribusi penelitian ini, yaitu secara teoritis diharapkan dapat digunakan sebagai salah satu referensi tambahan dalam bidang ilmu manajemen bisnis, serta secara praktis hasil penelitian ini diharapkan dapat digunakan sebagai aspek pertimbangan dan saran bagi Gojek Indonesia pada regional Bali khususnya di Kota Denpasar dalam merumuskan kebijakan agar manajemen serta seluruh stakeholder yang terlibat bisa meningkatkan hal-hal yang sifatnya mampumenciptakan dan membangunkeunggulan bersaing perusahaan dengan memerhatikan inovasi produk terhadap orientasi teknologi.

Dalam literatur manajemen teknologi, orientasi teknologi pada dasarnya dilihat sebagai sarana untuk menciptakan produk baru. Namun, dipertegas dengan pemberdayaan teknologi secara efektif(yaitu, skill teknis, keterampilan) daripada 
teknologi yang hanya menjelaskan mengapa perusahaan berbeda dalam hasil akhir dari upaya inovasi (Lindman, 2000). Orientasi teknologi mencerminkan filosofi "technological push," yang menunjukkan bahwa perusahaan lebih memilih produk dan layanan yang unggul secara teknologi (Wind dan Mahajan, 1997).Perusahaan dengan orientasi teknologi dapat mengembangkan oportunisme teknologi dalam fase generasi produk baru dengan mengambil tindakan spesifik seperti berfokus pada masa depan, dengan meminta manajemen puncak mengadvokasi teknologi baru, dan dengan menjadi lebih dari sekedar budaya adhokrasi dan memperkenalkan teknologi canggih secara luas (Srinivasan et al., 2002). Rajala dan Westerlund (2012) menyatakan bahwa orientasi teknologi memiliki indikator diantaranya adalah penyempurnaan, pilihan, efisiensi, implementasi serta eksekusi dalam pengembangan sistem informasi.

Menurut Buchari (2004) inovasi berarti mengamati konsumen untuk menemukan serta memuaskan konsumennya dengan memberikan produk yang baru. Oleh karena itu, perusahaan dituntut untuk mampu menciptakan pemikiran, gagasan baru dan menawarkan produk yang inovatif serta peningkatan pelayanan yang memuaskan pelanggan.Hurley dan Hult (1998) menyatakan bahwa inovasi produk merupakan salah satu dampak dari perubahan teknologi yang cepat dan variasi produk yang tinggi. Inovasi yang tinggi baik itu inovasi proses maupun inovasi produk akan meningkatkan kemampuan perusahaan untuk menciptakan produk yang berkualitas. Perusahaan dituntut untuk terus berinovasi terhadap produk maupun layanan mereka, karena jika tidak dinamis dalam beradaptasi, maka perusahaan akan tertinggal dan tidak mampu bersaing. Inovasi dapat meningkatkan 
kemampuan perusahaan untuk menghadapi ketidakpastian seperti yang terjadi saat ini, diantaranya dengan mencari peluang baru dan memanfaatkan yang sudah ada secara lebih efisien (Matzler et al., 2013). Dinyatakan oleh Cahyo dan Haryanti (2013) indikator yang digunakan untuk mengukur inovasi produk meliputi (1) kemampuan menciptakan dan mengembangkan ide-ide baru, (2) menciptakan desain yang menarik, (3) penambahan produk baru, (4) dan pengembangan kualitas produk.

Sigalas et al. (2013) menyebutkan bahwa keunggulan bersaing adalah industri di atas rata-rata dalam memanifestasikan eksploitasi peluang pasar dan netralisasi ancaman kompetitif. Keunggulan bersaing berfokus pada penciptaan nilai yang lebih besar bila dibandingkan dengan pesaing (Newbert, 2008). Teece et al. (1997) membahas tentang perlunya mengkonfirmasi bahwa kapabilitas tidak dapat segera ditiru oleh para pesaing yang tergantung pada kemampuan replikasi internal, maka dari itu kapabilitas atau kemampuan tersebut menjadi lebih bernilai dan juga akan menjadi langka di antara kompetitor.Dalam penelitian Sensi Tribuana Dewi (2006) ada tiga indikator yang digunakan untuk mengukur keunggulan bersaing diantaranya (1)keunikan produk, (2)kualitas produk,(3)dan harga yang bersaing.

Penelitian mengenai orientasi teknologi terhadap inovasi produk pernah dilakukan oleh Liu dan Su (2014), hasil penelitian tersebut menunjukkan bahwa orientasi teknologi mempunyai pengaruh positif terhadap kesuksesan inovasi produk. Salavou (2005) menyatakan bahwa orientasi teknologi mempunyai pengaruh positif terhadap inovasi produk pada UKM di Yunani. Mardiyono (2018) 
menemukan hasil bahwa orientasi teknologi berpengaruh positif signifikan terhadap inovasi produk. Berdasarkan hasil penelitian empiris yang ada, maka dapat disusun hipotesis sebagai berikut:

H1 : Orientasi teknologi berpengaruh positif dan signifikan terhadap inovasi produk

Penelitian yang dilakukan oleh Ibrahim dan Shariff (2016) menyatakan bahwa strategi orientasi salah satunya yaitu orientasi teknologi dapat menyebabkan terwujudnya daya saing yang unggul. Halac (2015) mengemukakan bahwa orientasi teknologi memberikan peran positif bagi keunggulan bersaing perusahaan. Penelitian yang dilakukan oleh Urban dan Barreira (2009) dengan judul Empirical Investigations into Firm Technology Orientation and Entrepreneurial Orientationmendapati hasil bahwa adanya pengaruh positif orientasi teknologi terhadap keunggulan bersaing. Selaras dengan penelitian yang dilakukan oleh Galbraith et al. (2008), Kuratko \& Audretsch (2009), serta penelitian dari Binneman dan Steyn (2014) menyatakan bahwa orientasi teknologi berpengaruh positif untuk menciptakan daya saing kompetitif.Berdasarkan hasil penelitian terdahulu, maka hipotesis yang disusun adalah sebagai berkut.

H2 : Orientasi teknologi berpengaruh positif dan signifikan terhadap keunggulan bersaing

Mardiyono (2018) menyatakan bahwa terdapat pengaruh positif signifikan antara inovasi produk terhadap keunggulan bersaing, sehingga semakin tinggi daya inovasi maka semakin tinggi daya saing kompetitif yang dihasilkan oleh perusahaan. Hasil penelitian Supriyanto et al. (2017) menunjukkan bahwa inovasi 
produk secara langsung berpengaruh positif dan signifikan terhadap keunggulan bersaing pada UKM Kopiah Haji yang terdapat di Kabupaten Hulu Sungai Tengah.Hasil tersebut selaras dengan penelitian yang dilakukan Curatman et al. (2016) dan Kurniasari (2018) yang menyatakan bahwa inovasi produk memiliki pengaruh positif dan signifikan terhadap keunggulan bersaing. Berdasarkan hasil penelitian empiris tersebut, maka dapat disusun hipotesis sebagai berikut.

H3 : Inovasi produk berpengaruh positif dan signifikan terhadap keunggulan bersaing

Penelitian yang dilakukan oleh Bakshi (2015) menyatakan bahwa intellectual capitalterkait dengan orientasi teknologi secara langsung dan signifikan berpengaruh positif terhadap keunggulan bersaing pada Bank umum dan swasta yang beroperasi di Kota Jammu, India Utara dengan daya inovasi sebagai mediator antara kedua variabel tersebut. Penelitian mengenai The influence of intellectual capital on the types of innovative capabilitiesmenunjukkan dengan daya inovasi sebagai variabel pemediasi,Subramaniam dan Youndt (2005) mendapati hasil bahwa orientasi teknologi memiliki peran yang signifikan dalam membangun keunggulan bersaing suatu perusahaan. Selaras dengan itu, Aloulou (2018) menyatakan bahwa inovasi merupakan bagian karakteristik dari orientasi kewirausahawan yang salah satu karakteristik tersebut yaitu daya inovasi mampu memediasi hubungan antara orientasi teknologi terhadap kinerja dalam menciptakan keunggulan bersaing pada perusahaan industri Arab Saudi.Makadari hasil penelitian empiris yang ada, dapat disusun hipotesis sebagai berikut. 
H4 : Inovasi produk berperan memediasi secara signifikan pengaruh orientasi teknologi terhadap keunggulan bersaing

Berdasarkan hasil-hasil studi empiris diatas maka model penelitian ini dapat digambarkan sebagai berikut.

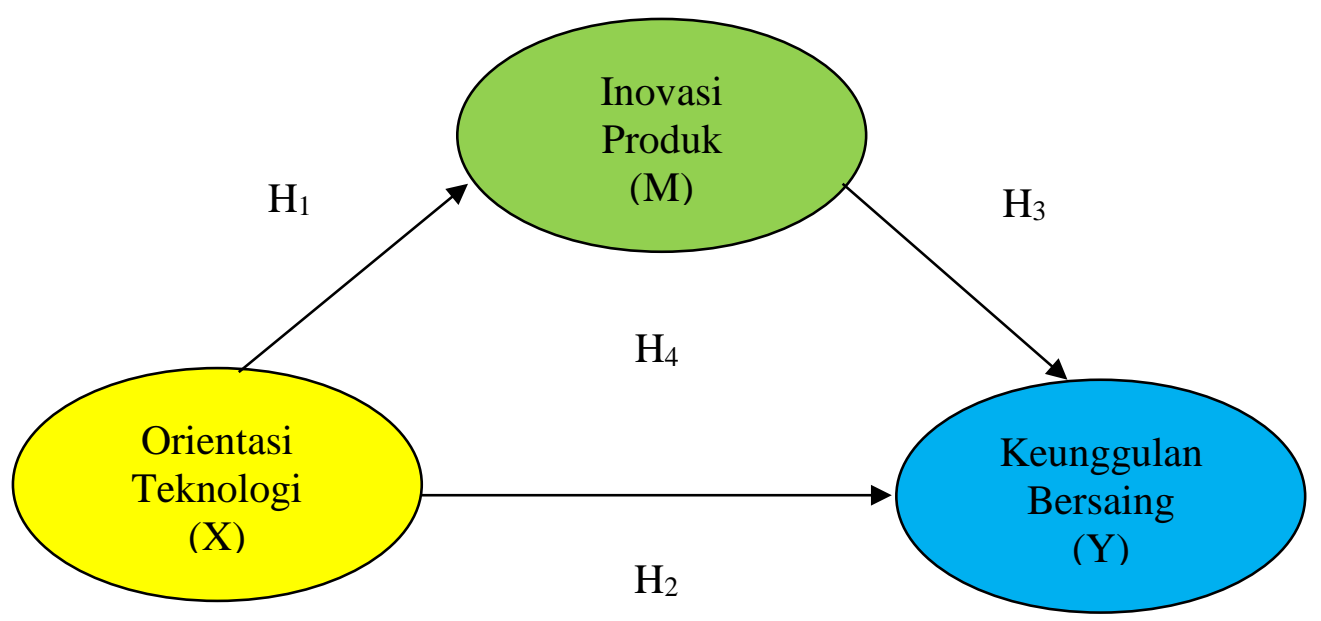

Sumber: Data Diolah, 2019

\section{Gambar 1.}

Model Penelitian

\section{METODE PENELITIAN}

Penelitian ini bermaksud untuk mengetahui peran inovasi produk dalam memediasi hubungan antara orientasi teknologi terhadap keunggulan bersaing pada salah satu perusahaan startup Indonesia yaitu Gojek regional Bali pada area operasi di Kota Denpasar dan sekitarnya. Lokasi ini dipilih karenamayoritas masyarakat telah memanfaatkan penggunaan layananinternet-mobile. Berdasarkan fenomena yang diamati langsung, masyarakat yang menggunakan layanan Gojek sangat tinggi diikuti dengan padatnya persaingan antara Gojek dengan kompetitornya. 
Tabel 1.

Klasifikasi Variabel dan Indikator Penelitian

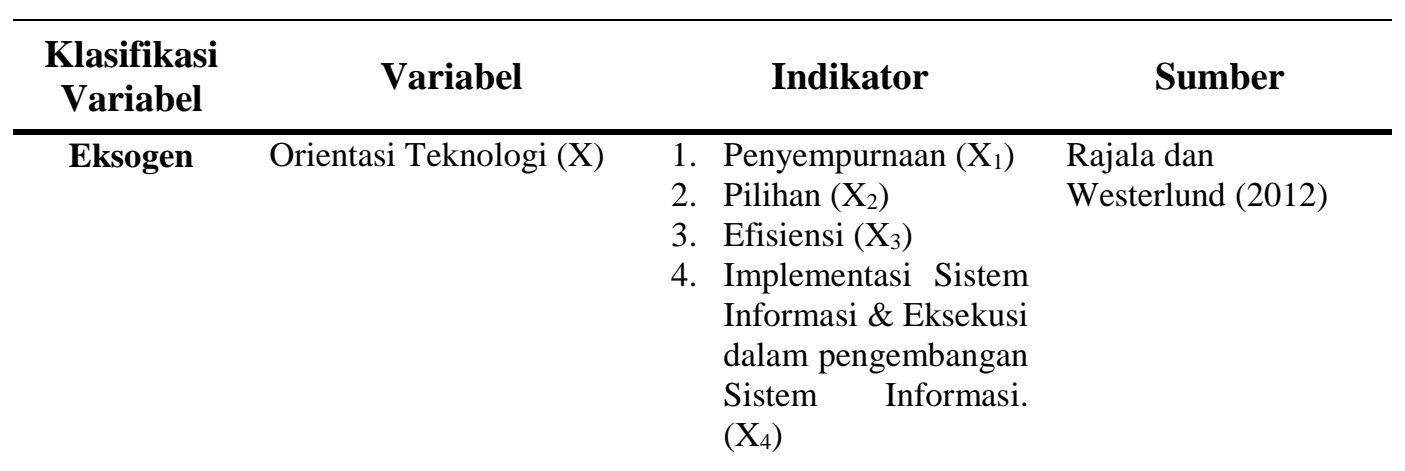

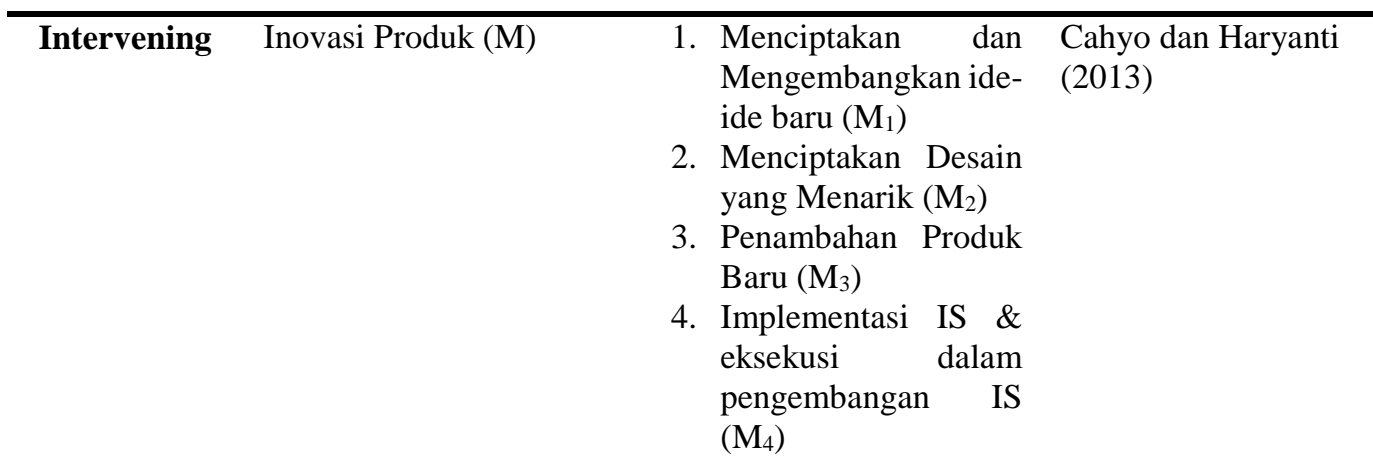

$\begin{array}{llll}\text { Endogen } & \text { Keunggulan Bersaing }(\mathrm{Y}) & \text { 1. } & \text { Keunikan Produk } \\ & \left(\mathrm{Y}_{1}\right) & \begin{array}{l}\text { Dewi, Sensi Tribuana } \\ (2006)\end{array} \\ & \text { 2. Kualitas Produk }\left(\mathrm{Y}_{2}\right) & \\ & \text { 3. Harga Bersaing }\left(\mathrm{Y}_{3}\right) & \end{array}$

Sumber: Kajian Penelitian Sebelumnya, 2019

Jenis data pada penelitian ini, yaitu data kuantitatif dan kualitatif serta sumber data penelitian ini, yaitu dari sumber data primer dan sekunder. Variabel penelitian ini, yaitu Orientasi Teknologi (X), Inovasi Produk (M), dan Keunggulan Bersaing (Y).Populasi pada penelitian ini adalah masyarakat yang telah memanfaatkan penggunaan layanan aplikasi Gojek dalam mendukung proses ataupunyang terkait dengan kegiatan sehari-hari di Kota Denpasar dan sekitarnya. Terdapat 11 indikator yang berarti dibutuhkan sampel minimal adalah 55 (11x5) dan maksimal $110(11 \times 10)$. 
Penelitian ini menggunakan 62 sampel yang berarti telah memenuhi kriteria yaitu minimal 55 dan maksimal 110. Teknik pengambilan sampel dengan metode non-probability samplingcarapurposive sampling pada karakteristik responden dalam penelitian yaitu yang bertempat tinggal di Kota Denpasar, berusia minimal 17 tahun dan minimal berpendidikan SMA. Data yang diperlukan diperoleh melalui cara penyebaran kuesioner pertanyaan secara online dengan pemberdayaan Google form yang dapat diakses melalui media elektronik dengan berjaringan internet.Penelitian ini menggunakan skala Likert dengan asumsi bahwa skala ini menghasilkan pengukuran suatu variabel dengan skala interval. Setelah itu, data kemudian diproses dan diolah menggunakan teknik analisis jalur dan uji sobel.

\section{HASIL DAN PEMBAHASAN}

Berdasarkan hasil pengumpulan data, karakteristik responden pada penelitian ini memiliki deskripsi sebagai berikut.

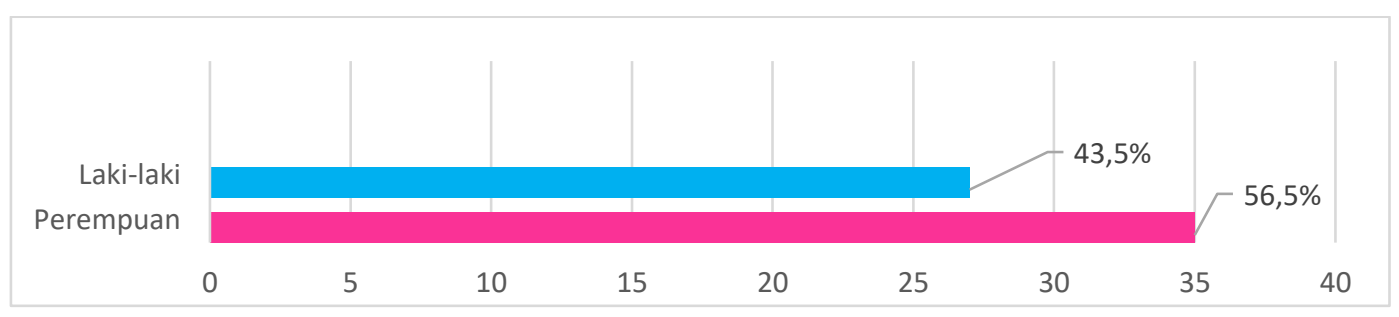

Sumber: Data Diolah, 2019

Grafik 2.

Grafik Gender dan Jumlah Responden 


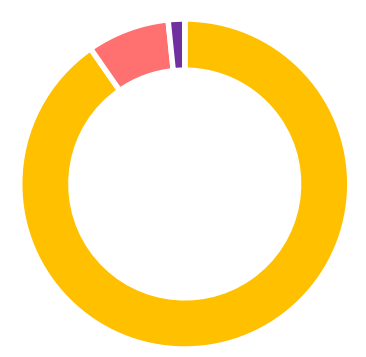

-17-21 Tahun

- 22-26 Tahun

- 33-38 Tahun

Sumber: Data Diolah, 2019

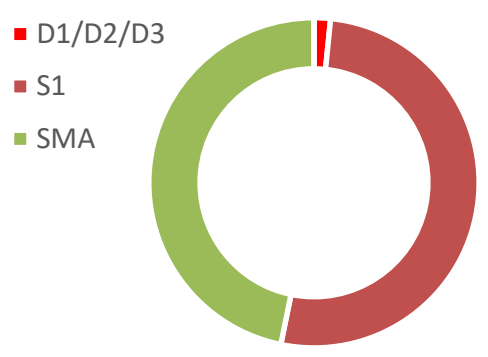

Sumber: Data Diolah, 2019
Grafik 3.

Grafik Usia

\section{Grafik 4.}

\section{Grafik Pendidikan}

Total keseluruhan 62 responden yang turut berpartisipasi, pengelompokan responden berdasarkan gender menunjukkan bahwa jumlah responden laki-laki dengan persentase 43,5 persen dan responden perempuan dengan persentase 56,5 persen (Gambar 2). Pengelompokan responden berdasarkan usia 17-21 tahun dengan persentase sebesar 90,3 persen, responden dengan usia 22-26 tahun dengan persentase 8,1 persen, dan responden berusia 33-38 tahun memiliki tingkat persentase 1,6 persen (Gambar 3). Dapat dijelaskan pada gambar 4 yaitu, tingkat persentase responen yang berpendidikan SMA sebesar 46,8 persen, jenjang Sarjana 1 sejumlah 51,6 persen, dan pada tingkat pendidikan Diploma sebesar 1,6 persen.

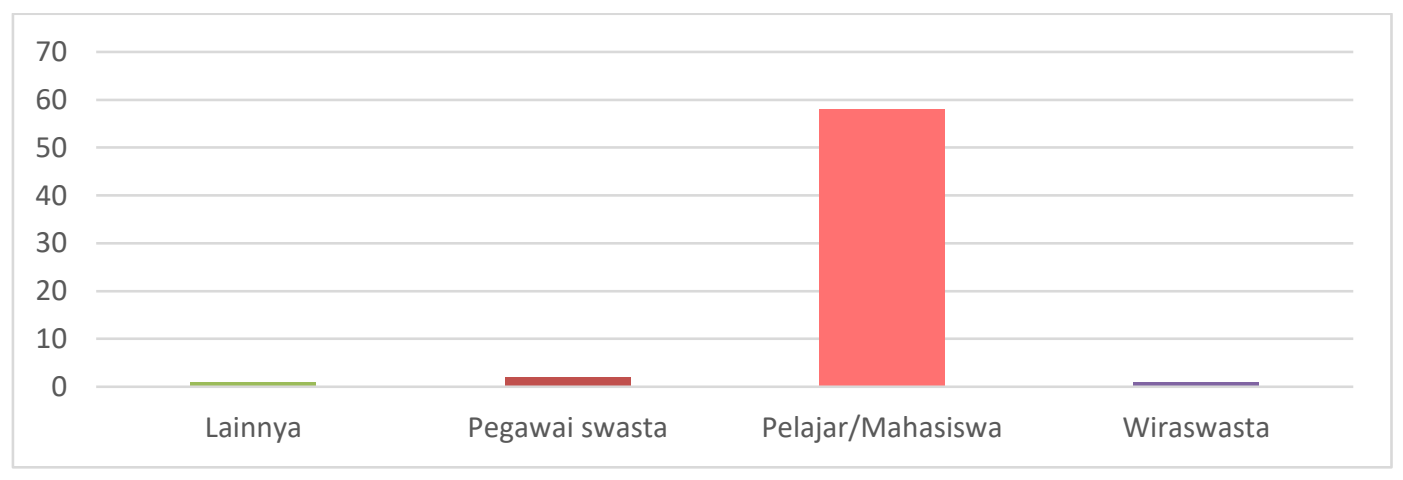

Sumber: Hasil Pengolahan Data Penelitian, 2019

Grafik 5.

Grafik Pekerjaan 
Berdasarkan Grafik 5, dapat diketahui bahwa tingkat persentase responden yang turut terlibat mayoritas pekerjaannya adalah sebagai pelajar atau mahasiswa sebesar 93,5 persen, diikuti oleh responden pegawai swasta sebesar 3,2 persen, persentase responden yang pekerjaanya sebagai wiraswasta sebesar 1,6 persen, dan besaran yang sama juga di dapat dari pengelompokan pekerjaan lainnya sebesar 1,6 persen.

Dalam penelitian ini, validitas instrumen diuji dengan Pearson Correlation. Berdasarkan Tabel 2.bahwa nilai pearson correlation pada seluruh indikator menunjukkan nilai yang lebih besar dari angka 0,30 yang berarti indikator-indikator pada variabel Orientasi Teknologi, Inovasi Produk, dan Keunggulan Bersaing telah memenuhi syarat validitas data layak digunakan sebagai instrumen penelitian.

Tabel 2. Hasil Uji Validitas

\begin{tabular}{cccc}
\hline Variabel & Instrumen & Pearson Correlation & Keterangan \\
\hline Orientasi Teknologi & X1 & 0,611 & Valid \\
& X2 & 0,775 & Valid \\
& X3 & 0,811 & Valid \\
& X4 & 0,656 & Valid \\
\hline Inovasi Produk & M1 & 0,769 & Valid \\
& M2 & 0,682 & Valid \\
& M3 & 0,811 & Valid \\
& M4 & 0,672 & Valid \\
\hline Keunggulan Bersaing & Y1 & 0,815 & Valid \\
& Y2 & 0,789 & Valid \\
& Y3 & 0,788 & Valid \\
\hline
\end{tabular}

Sumber: Hasil Pengolahan Data Penelitian, 2019

Uji realibilitas dalam penelitian ini diukur menggunakan Alpha Cronbach. Berdasarkan Tabel 3. dapat dinyatakan bahwa seluruh instrumen penelitian ini mempunyai koefisien cronbach's alpha melebihi 0,60 (reliable). 
Tabel 3.

Hasil Uji Realibilitas

\begin{tabular}{ccc}
\hline Variabel & Cronbach's Alpha & Keterangan \\
\hline Orientasi Teknologi & 0,683 & Reliabel \\
Inovasi Produk & 0,699 & Reliabel \\
Keunggulan Bersaing & 0,708 & Reliabel \\
\hline Sumber: Hasil Pengolahan Data Penelitian, 2019 &
\end{tabular}

Selanjutnya, Tabel 4. dan Tabel 5. tentang hasil koefisien jalur persamaan regresi 1 dan persamaan regresi 2 .

Tabel 4.

Hasil Analisis Jalur Persamaan Regresi 1

\begin{tabular}{|c|c|c|c|}
\hline \multirow{2}{*}{ Model } & \multirow{2}{*}{ R. Square } & Standardized Coefficient & \multirow{2}{*}{ Sig. } \\
\hline & & Beta & \\
\hline Orientasi Teknologi & 0,548 & 0,740 & 0,000 \\
\hline
\end{tabular}

Berdasarkan Tabel 5. Berikut adalah kesimpulan persamaan strukturalnya.

$$
\begin{aligned}
& M=\beta_{1} X+e_{1} \ldots \\
& M=0,740 X+e_{1}
\end{aligned}
$$

\section{Tabel 5}

\section{Hasil Analisis Jalur Persamaan Regresi 2}

\begin{tabular}{clll}
\hline Model & R. Square & $\begin{array}{l}\text { Standardized } \\
\text { Coefficient }\end{array}$ & \multirow{2}{*}{ Sig. } \\
\hline $\begin{array}{c}\text { Orientasi Teknologi } \\
\text { Inovasi Produk }\end{array}$ & 0,780 & $\begin{array}{l}0,375 \\
0,568\end{array}$ & 0,000 \\
\hline
\end{tabular}

Sumber: Hasil Pengolahan Data Penelitian, 2019

Berdasarkan hasil pada Tabel 5. maka persamaan strukturalnya adalah sebagai berikut:

$$
\begin{aligned}
& \mathrm{Y}=\beta_{2} \mathrm{X}+\beta_{3} \mathrm{Y}+\mathrm{e}_{2} \ldots \ldots \ldots \\
& \mathrm{Y}=0,375 \mathrm{X}+0,568 \mathrm{Y}+\mathrm{e}_{2}
\end{aligned}
$$


Berdasarkan hasil analisis Pengaruh Orientasi Teknologi terhadap Keunggulan Bersaing diperoleh Sig. t senilai 0,000 dengan nilai koefisien beta 0,375. Nilai Sig. t $0,000<0,05$ menandakan bahwa $\mathrm{H}_{0}$ ditolak dan $\mathrm{H}_{1}$ diterima. Hasil ini memiliki makna bahwa Orientasi Teknologi berpengaruh positif signifikan dan signifikan terhadap Keunggulan Bersaing. Berdasarkan hasil analisis Pengaruh Orientasi Teknologi terhadap Inovasi Produk diperoleh Sig t. senilai 0,000 dengan nilai koefisien beta 0,740. Nilai Sig t. $0,000<0,05$ menandakan bahwa $\mathrm{H}_{0}$ ditolak dan $\mathrm{H}_{1}$ diterima. Hasil ini memiliki makna bahwa Orientasi Teknologi berpengaruh positif dan signifikan terhadap Inovasi Produk. Berdasarkan hasil analisis pengaruh Inovasi Produk terhadap Keunggulan Bersaing diperoleh Sig t. senilai 0,000 dengan nilai koefisien beta 0,568. Nilai Sig t. $0,000<0,05$ menandakan bahwa $\mathrm{H}_{0}$ ditolak dan $\mathrm{H}_{1}$ diterima. Hasil ini memiliki makna bahwa Inovasi Produk berpengaruh positif dan signifikan terhadap Keunggulan Bersaing.

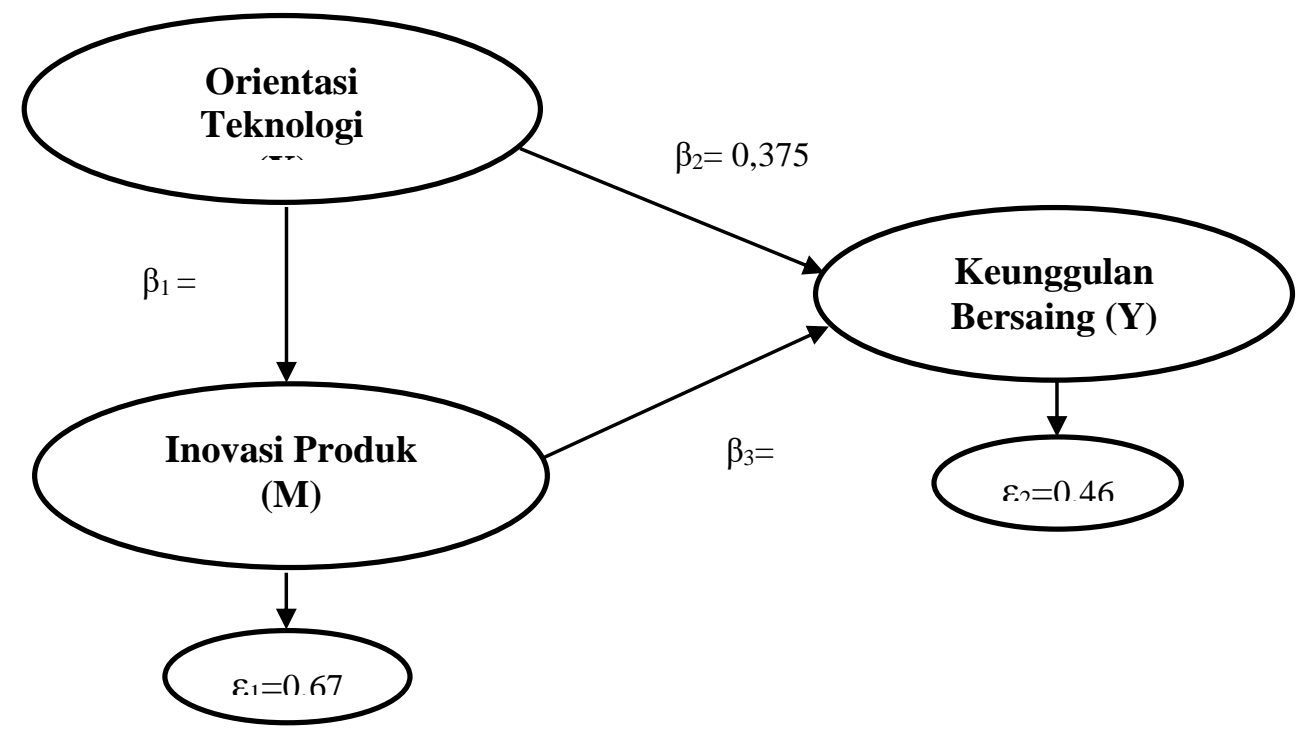

Sumber: Hasil Pengolahan Data Penelitian, 2019

Gambar 2.

Validasi Model Diagram Jalur Akhir 
Berdasarkan Grafik 6. dapat dihitung besarnya pengaruh langsung dan tidak langsung serta pengaruh keseluruhan antar variabel. Perhitungan pengaruh antar variabel terangkum dalam Tabel 6.

Tabel 6.

Pengaruh Langsung, Pengaruh Tidak Langsung, serta Pengaruh Total Orientasi Teknologi (X), Inovasi Produk (M), dan Keunggulan Bersaing (Y)

\begin{tabular}{cccc}
\hline $\begin{array}{c}\text { Pengaruh } \\
\text { Variabel }\end{array}$ & $\begin{array}{c}\text { Pengaruh } \\
\text { Langsung }\end{array}$ & $\begin{array}{c}\text { Pengaruh Tidak Langsung } \\
\text { Melalui Inovasi Produk }(\mathbf{M}) \\
\left(\boldsymbol{\beta}_{\mathbf{1}} \boldsymbol{\beta}_{\mathbf{3}}\right)\end{array}$ & Pengaruh Total \\
\hline $\mathrm{X} \rightarrow \mathrm{M}$ & 0,740 & - & 0,740 \\
$\mathrm{X} \rightarrow \mathrm{Y}$ & 0,375 & 0,420 & 0,795 \\
$\mathrm{M} \rightarrow \mathrm{Y}$ & 0,568 & - & 0,568 \\
\hline
\end{tabular}

Sumber: Hasil Pengolahan Data Penelitian, 2019

Pengujian mediasi dalam penelitian ini dilaksanakan dengan Uji Sobel dan terangkum dalam Tabel 7.

Tabel 7.

Hasil Uji Sobel

\begin{tabular}{lll}
\hline & Nilai & Keterangan \\
\hline $\mathrm{Z}$ & 4,327 & Memediasi \\
Sig. & 0,000 & Signifikansi \\
\hline
\end{tabular}

Sumber: Hasil Pengolahan Data Penelitian, 2019

Dengan nilai $\mathrm{Z}$ sebesar 4,327 yang lebih besar dari nilai yang ditentukan yaitu 1,96 dengan tingkat signifikansi 0,000, lebih kecil dari 0,05. Maka, hal ini menunjukkan bahwa inovasi produk secara signifikan mampu memediasi orientasi teknologi terhadap keunggulan bersaing.

Pengaruh hipotesis pada pengaruh Orientasi Teknologi terhadap Inovasi Produk menunjukkan bahwa Orientasi Teknologi secara signifikan berpengaruh positif terhadap Inovasi Produk. Ini berarti semakin baiknya orientasi teknologi yang terimplementasikan maka semakin tinggi daya inovasi produk yaitu mampu 
mengembangkan desain serta kualitas produk yang berbeda dari pesaing sehingga dapat bertahan sejalan dengan perkembangan masa.

Hasil penelitian ini mendukung beberapa temuan dari peneliti terdahulu seperti Liu dan Su (2014), Salavou (2005), serta Mardiyono (2018) yang menjelaskan bahwa Orientasi Teknologi berpengaruh secara positif dan signifikan terhadap Inovasi Produk.

Pengaruh hipotesis pada pengaruh Orientasi Teknologi terhadap Keunggulan Bersaing menunjukkan bahwa Orientasi Teknologi secara signifikan berpengaruh positif terhadap Keunggulan Bersaing. Ini berarti semakin optimal orientasi teknologi yang ada maka semakin kuat terwujudnya daya saing yang unggul yaitu tercermin dengan semakin kuat penerapan pengetahuan dan kapabilitas teknologi, semakin tinggi kemampuan perusahaan dalam mewujudkan nilai saing yang kompetitif.

Hasil penelitian ini mendukung temuan dari Ibrahim dan Shariff (2016), Halac (2015), Urban dan Barreira (2009), Galbraith et al. (2008), Kuratko dan Audretsch (2009), serta Binneman dan Steyn (2014) yang menjelaskan bahwa Orientasi Teknologi berpengaruh secara positif dan signifikan terhadap Keunggulan Bersaing.

Pengaruh hipotesis pada pengaruh Inovasi Produk terhadap Keunggulan Bersaing menunjukkan bahwa Inovasi Produk secara signifikan berpengaruh positif terhadap Keunggulan Bersaing. Ini berarti semakin optimalnya kualitas dari pengembangan produk yang terterapkan, maka semakin baik dan kuat daya saing perusahaan dibanding kompetitor dalam mendominasi target pasar dari aspek 
kemampuan dalam berinovasi terkait dengan pemberdayaan sumber daya guna menghasilkan suatu kreasi yang unik dan berkualitas.

Hasil penelitian ini mendukung hasil temuan dari Supriyanto et al. (2017), Mardiyono (2018), Curatman et al. (2016) dan Kurniasari (2018) yang menjelaskan bahwa Inovasi Produk berpengaruh secara positif dan signifikan terhadap Keunggulan Bersaing.

Pengaruh hipotesis pada peran Inovasi Produk dalam memediasi Orientasi Teknologi terhadap Keunggulan Bersaing pada perusahaan Startup Gojek Indonesia di Kota Denpasar mendapatkan hasil bahwa Inovasi Produk mampu memediasi pengaruh Orientasi Teknologi dengan Keunggulan Bersaing Gojek Indonesia di Kota Denpasar. Ini berarti Inovasi Produk memediasi pengaruh Orientasi Teknologi ke Keunggulan Bersaing secara parsial. Dengan kata lain, Inovasi Produk memperkuat pengaruh Orientasi Teknologi ke Keunggulan Bersaing yang semula bernilai 0,375 namun setelah adanya Inovasi Produk sebagai variabel mediasi pengaruh Orientasi Teknologi ke Keunggulan Bersaing meningkat menjadi 0,795. Hasil penelitian ini mendukung temuan dari Bakshi (2015), Subramaniam dan Youndt (2005), serta Aloulou (2018) yang menyatakan bahwa Inovasi Produk mampu memediasi Orientasi Teknologi terhadap Keunggulan Bersaing.

\section{SIMPULAN DAN SARAN}

Berdasarkan hasil analisis dan pembahasan, maka dapat disimpulkan sebagai berikut: (1) Orientasi teknologi berpengaruh positif dan signifikan terhadap inovasi produk yang berarti, orientasi teknologi mampu meningkatkan daya inovasi 
dari startup Gojek Indonesia (2) Orientasi teknologi berpengaruh positif signifikan terhadap keunggulan bersaing, yang artinya semakin tinggi orientasi teknologi yang dimiliki oleh startup Gojek Indonesia, maka mampu meningkatkan kemampuan daya saing perusahaan. (3) Inovasi produk berpengaruh positif dan signifikan terhadap kenggulan bersaing yang artinya semakin optimal inovasi produk yang dilakukan, akanmampu mewujudkan dan meningkatkan daya saing yang unggul. (4) Inovasi produk mampu memediasi secara signifikan hubunganantara orientasi teknologi dan keunggulan bersaing. Jika Gojek Indonesia berorientasi pada teknologi dengan baik maka aspek orientasi teknologi tersebut mampu meningkatkan inovasi produk dan pada akhirnya mampu menciptakan serta membangun daya saing yang unggul pada Gojek Indonesia regional Bali yang beroperasi di Kota Denpasar.

Penelitian yang dilakukan terkait tentang Keunggulan Bersaing, Inovasi Produk, serta Orientasi teknologi ini dapat diperuntukan sebagai salah satu referensi dalam bidang ilmu manajemen bisnis, khususnya pada peranan antara masingmasing variabel terkait dengan dampaknya dari segi perencanaan, penerapan, pengelolaan, serta evaluasi terhadap kegiatan bisnis pada perusahaan Startup. Penelitian ini dapat digunakan sebagai opsi pertimbangan dan saran teruntuk Gojek Indonesia regional Bali yang beroperasi di Kota Denpasar dalam merumuskan kebijakan agar manajemen serta seluruh elemen individu ataupun kelompok yang terlibat dapat meningkatkan aspek yang sifatnya membangun serta dalam menciptakan keunggulan bersaing perusahaan dengan memerhatikan daya inovasi produk terhadap orientasi teknologi. 
Adapun saran-saran yang dapat diberikan dalam penelitian ini, yaitu bagi Gojek Indonesia disarankan untuk selalu meningkatkan orientasi teknologi dengan pengembangan pengetahuan serta kapabilitas teknologi serta informasi dan terus melakukan inovasi pada produk sebab akan memengaruhi keunggulan bersaing perusahaan. Bagi penelitian selanjutnya yang terkait dengan penelitian ini disarankan agar memperluas ruang lingkup penelitian atau menggunakan obyek penelitian lain seperti perusahaan startup yang bergerak di sektor $e$-commerce yang kemungkinan memiliki potensi yang serupa dengan startup Gojek Indonesia.

\section{REFERENSI}

Aloulou, W., J. 2018. Impacts of strategic orientations on new product development and firm performances: Insights from Saudi industrial firms. European Journal of Innovation Management.

Antoniou, P. H. and Ansoff, I. 2004. Strategic Management of Technology. Technology Analysis \& Strategic Management, 16 (2), 275-291.

Atalay, M., Anafarta, N., and Sarvan, F. 2013. The Relationship between Innovation and Firm Performance: An Empirical Evidence from Turkish Automotive Supplier Industry, Procedia - Social and Behavioral Sciences, 75 (2), 226-235.

Bakshi, H., C., P. 2015. Examining Intellectual Capital and Competitive Advantage Relationship: Role of Innovation and Organizational Learning. International Journal of Bank Marketing, 33 (3).

Binneman, B. and Steyn, H. 2014.Criteria for Selection and Gate Reviews of Technology Innovation Projects. South African Journal of Industrial Engineering, 25, 117-130.

Buchari, A., 2004. Manajemen Pemasaran dan Pemasaran Jasa.Alfabeta, Bandung.

Cahyo, J.K., dan Haryanti, D. 2013. Analisa Inovasi Produk Pada Sektor Usaha Formal dan Informasi di Jawa Timur. Jurnal AGORA, 1 (3), 1-5.

Curatman, A., Rahmadi., Maulany, S., dan Ikhsani, M. M. 2016. Analisis Faktorfaktor Pengaruh Inovasi Produk yang Berdampak pada Keunggulan Bersaing 
UKM Makanan dan Minuman di Wilayah Harjamukti Kota Cirebon. Jurnal Logika, 18 (3), 61-75.

Day, G. S. 1994. The Capabilities of Market Driven Organizations. Journal of Marketing, 58, 37-52.

Dewi, Sensi Tribuana. 2006. Analisis Pengaruh Orientasi Pasar Dan Inovasi Produk Terhadap Keunggulan Bersaing Untuk Meningkatkan Kinerja Pemasaran (Studi Pada Industri Batik Di Kota Dan Kabupaten Pekalongan).Masters Thesis, Program Pascasarjana Universitas Diponegoro.

Galbraith, C.S., Rodriquez, C.L., and De Noble,A.F. 2008. SME Competitive Strategy and Location Behaviour: An Exploratory Study of High-Technology Manufacturing.Journal of Small Business Management, 46, 183-202.

Gatignon, H. and Xuereb, J. M. 1997. Strategic Orientation of the Firm New Product Performance. Journal of Marketing Research, 34 (1), 77-90.

Gojek Indonesia. 2019. About Us. Diunduh tanggal 14 April 2019. https://www.gojek.com

Halac, D. S. 2015. Multidimensional Construct of Technology Orientation. World Conference on Technology, Innovation and Entrepreneurship, 195, 10571065.

Helen, Salavou .2005. Do Customer and Technology Orientations Influence Product Innovativeness in SMEs? Some New Evidence from Greece, Journal of Marketing Management, 21 (3-4), 307-338.

Hurley, R. and Hult, G.T. 1998. Innovation, Market Orientation and Organizational Learning: An Integration and Empirical Examination. Journal of Marketing, 62(3), 42-54.

Ibrahim, M. A. and Shariff, M. N. M. 2016. Mediating Role of Access to Finance on the Relationship between Strategic Orientation Attributes and SMEs Performance in Nigeria. International Journal of Business and Society, 17 (3), 473-496.

Katadata. 2019. Dikabarkan Jadi Decacorn, Gojek: Pangsa Pasar Kami Tertinggi. Diunduh tanggal 14 April 2019.https://katadata.co.id

Katadata. 2019. Indonesia Memiliki 2.000 Startup. Diunduh tanggal 14 April 2019. https://databoks.katadata.co.id 
Kompas. 2019. Grab Jadi Startup Decacorn Pertama di Asia Tenggara. Diunduh tanggal 14 April 2019.https://ekonomi.kompas.com

Kotler, P. dan Gary, A. 2008. Prinsip-Prinsip Pemasaran, Edisi, Terjemahan: Damos Sihombing. Jakarta: Erlangga.

Kuratko, D. F. and Audretsch, D. B. 2009. Strategic Entrepreneurship: Exploring Different Perspectives of an Emerging Concept, Entrepreneurship Theory and Practice, 25, 1-17.

Kurniasari, R. D. 2018. Pengaruh Inovasi Produk, Kreativitas Produk, dan Kualitas Produk terhadap Keunggulan Bersaing. Skripsi. Universitas Negeri Yogyakarta.

Lin, C. Y. and Chen, M. Y. 2007. Does Management Research News. Vol. 30 Marketing Performance. Journal of Service, 16 (3), 115-132.

Liu, J. and Su, J. 2014. Market Orientation, Technology Orientation and Product Innovation Success: Insights from Cops. International Journal of Innovation Management, 18 (4), 1-25

Mardiyono, Aris. 2018. The Effect of Market Orientation, Technology Orientation to Increase Marketing Performance on Confection Medium Small Business in Indonesia. Scholars Journal of Economics, Business and Management, 5 (7), 562-569.

Matzler, K., Abfalter, D. E., Mooradian, T. A., and Bailom, F. 2013. Corporate Cultureas an Antecedent of Successful Explorationand Exploitation. International Journal ofInnovation Management, 17 (5), 1-23.

Modalku. 2019. Sejarah Perkembangan Startup. Diunduh tanggal 14 April 2019.https://blog.modalku.co.id.

Mulyani, Ida Tri. 2015. Upaya Meningkatkan Kinerja Pemasaran Melalui Orientasi Pasar dan Orientasi Kewirausahaan dengan Inovasi sebagai Variabel Intervening. Skripsi, Fakultas Ekonomika dan Bisnis Universitas Diponegoro, Semarang.

Nakola, J. O., Tarus, B. K., Buigut, K., and Kipchirchir, K. E. 2015. Effect of Strategic Orientation on Performance of Small and Medium Enterprises: Evidence from Kenya.International Journal of Economics, Commerce and Management, 3 (11), 336-351.

Newbert, S. L. 2008. Value, Rareness, Competitive Advantage, and Performance: a Conceptual Level Empirical Investigation of the Resource-Based View of the Firm. Strategic Management Journal, 29 (7), 745-768. 
Porter, Michael, E. 2008. Strategi Bersaing (Competitive Strategy). Tangerang: Karisma Publishing Grup.

Rajala, R. and Westerlund, M. 2012. The Effects of Service Orientation, Technology Orientation and Open Innovation on the Performance of Software-Intensive Service Businesses.45th Hawaii International Conference on System Sciences, 1532-1541.

Sigalas, C. and Pekka-Economou, V. 2013. Revisiting the Concept of Competitive Advantage: Problems and Fallacies Arising from its Conceptualization. Journal of Strategy and Management, 6 (1), 61-80.

Subramaniam, M. and Youndt, M. 2005. The Influence of Intellectual Capital on the Types of Innovative Capabilities. Academy of Management Journal, 48 (3), 450-463.

Suendro, Ginanjar. 2010. Analisis Pengaruh Inovasi Produk Melalui Kinerja Pemasaran Untuk Mencapai Keunggulan Bersaing Berkelanjutan. Tesis, Universitas Diponegoro, Semarang.

Supriyanto, A., Sukrina, H. R., dan Abidin, M. Z. 2017. Pengaruh Orientasi Pasar dan Inovasi Produk terhadap Keunggulan Bersaing. Prosiding Seminar Nasional AIMI, 26-33.

Tung, J. 2012. A Study of Product Innovation on Firm Performance. The International Journal of Organizational Innovation, 4 (3), 83-97.

Urban, B. and Barreira, J. 2009. Empirical Investigations into Firm Technology Orientation and Entrepreneurial Orientation. International Journal of Innovation and Technology Management, 7, 1-23.

Winata, D. J. dan Devie. 2013. Analisa Pengaruh Aliansi Stratejik terhadap Keunggulan Bersaing dan Kinerja Perusahaan. Business Accounting Review, $1(2), 1-10$.

Zhou, K. Z., Yim, C. K. and Tse, D. K. 2005. The Effects of Strategic Orientations on Technology- and Market-Based Breakthrough Innovations. Journal of Marketing, 69, 42-60.

Zimmerer, T. W., and Norman M. S. 2002. Pengantar Kewirausahaan dan Manajemen Bisnis Kecil. Edisi Bahasa Indonesia. Pratiknyo, S dan Tarmidzi, E. T. Jakarta: PT Prenhallindo. 